\title{
包種茶史
}

(侏)伊藤園中央研究所*

竹尾忠一

(平成13年 2 月 20 日受理)

\section{History of Paochung Tea}

\section{1 はじめに}

福建に行き奇異に感じたことは，包種茶の 話をすると，多くの人はそれに興味を示さな いばりか知識も無いことと, 茶関係者からは 包種茶というと台湾包種茶のことかという返 答が返ってきたことである。

中国茶経を見ると包種茶として台湾包種 茶が記載されていて，鳥龍茶の項には包種茶 の記載はなく，そこから包種茶の起源由来を 見付けることは難しい。そこで福建省安渓で の包種茶誕生と台湾での包種茶発展の経緯を 調べてみることとした。

\section{2 包種茶の始まり}

福建で生まれた包種という茶の名称は, 新 しく造られた茶種を指していたのではない。 それは多くの通説が物語るように19世紀中期 福建省安渓の茶商王義程が, 自商店販売銘柄 の 1 つとして, 鳥龍茶四両，150gを方形の四 方包みの紙袋に詰め, その表面に茶名“包種”と 印刷して売り出したのが始まりで，その形態
から「四方包」という別称もある。

当時, “中国発醉茶” 'Bohea (福建北部武夷 山地部族が生産する発酵茶) 'が大量に広東か らロンドン市場に送り出されていて, 福建茶 業はみぞうの好景気の時代であった ${ }^{2)}$ 。Bohea の産地は始めは閩北地方であつたが，やがて 交通輸送に便利な閐南地方に主産地が移動 し,さらにBoheaの製造方法が改良されて, 外 観, 香味に勝る鳥龍茶が䦩南地方で造られ, 現在の中国鳥龍茶が誕生した。

これには一重に品種選抜の成功が大きく貢 献していた。代表的中国鳥龍茶「鉄観音」の 原料となる品種“鉄観音種”が, 安渓県西部“内 安渓”を囲む山中の茶畑から選抜されたのは 18世紀中期といわれている3。これが中国に おける品種選抜の最初の成果の 1 つであり， また同時に無性繁殖法による品種茶普及の始 まりといえる。その後19世紀中期にかけて 続々と鳥龍茶用の品種が閩南地方で誕生して くる。これら品種の特徵は茶芽を発酵させる と品種特有の強い花香が形成され, それが鳥 龍茶の香味を一段と高めるのに貢献した。

* ₹421-0516 静岡県榛原郡相良町女神21番地 
Boheaは闒北地方，とくに武夷山脈の山腹 に植栽されている喬木性大葉種の茶葉を原料 としていて，造られた茶は花香に欠け，その ため火香を強めて香味を補っていた。これに たいして安渓で選抜された品種は, 発䣲茶と すると強い花香が生まれてくる。鉄観音’の持 つ特徵的花香は, 茶香気成分中にネロリドー ルというテルペンアルコールを豊富に含んで いることによる4)。

他方，19世紀中期金炒茶の香味改善という 目的で着香茶が誕生し，北京で好評を博した。 これが現在の茉莉花茶 (ジャスミン茶) の涎 生である。ジャスミン茶は鉒炒茶にジャスミ ンの花香を着けて造られる茶で, 19世紀末福 州地方がジャスミン茶製造の中心地であっ た。

さて前述のようにBoheaはロンドン向け商 品として成長して来たのであるが，これが 1840年の阿片戦争を境として情勢が大きく変 わり, 中英関係の悪化とインドでの紅茶生産 の開始等が重なり, Boheaのロンドン向け販 路が失われて福建茶業は壊滅的な打擊を受け た。そこで鳥龍茶（19世紀代中国茶業界には Boheaという茶銘柄は無く, 紅茶の内に下級 品として烏龍茶=Boheaが分類されている の販路として東南アジアの華僑向け貿易が開 拓されたが，その販路拡大のために烏龍茶に 花香を着けて，華僑の嘫好にあう茶としよう というわけで，ジャスミン茶をまねた着香鳥 龍茶 (花香茶) が作られ，アモイから東南ア ジアに輸出された。これが福建包種茶の由来 である5)。

\section{3 台湾 古 茶}

台湾茶樹の起源は明代初期に溯るという説 があり，この茶は“蒔茶”といわれている6。 また台湾中南部山地の眉原山には野性茶樹が 自生していて，これは樹高 $18 \mathrm{~m}^{3}$ に及ぶ樹齢 100年を越える喬木性の大葉種 (assamica)の 茶樹である7)。また福建省農業科学院茶葉研 究所編著「茶樹品種志」にも“台湾大葉種’が登 録されていて，これも喬木性大葉種に分類さ れている8)。
これらの古茶樹を利用した島民による飲茶 の記録は無いが，台湾茶史に「1620年頃アモ イの住民が台湾に移住して来て, 彼等は好ん で茶を飲んでいたと」いう口伝が記載されて いるのと，1645年オランダによる台湾占領時 代バタビヤ城中日記に，台湾茶の記録9)が見 られることから，17世紀には福建からの移住 民による,茶の生産と飲茶の習慣が台湾に伝 わっていたと考えられる。

\section{4 福建からの茶樹渡来と烏龍茶の生産}

台湾への中国本土からの茶樹の伝来につい ての記録は，嘉慶時代（1796-1820）に「在台 の中国人（柯朝）が福建から武夷の茶樹を持 ち㛿り，これを鰈魚坑に植えたところ良く生 育し種子 2 斗を得てこれをまき增殖した。」と いう記録が始まりである5。。また陳培桂纂修

（1871）淡水庁志には「石碇，文山（拳山） の住民は茶栽培製造を行っていたが，道光年 間（1821-50）福州の商人が来たりて大陸伝来 の茶種子を蒔き繁殖させた。これを総称して 莳茶という。」とある ${ }^{10)}$ 。台湾の在来種に蒔茶 または時茶というのがあるが，蒔茶とは19世 紀前からの実生繁殖で増植されていた茶樹を 総称していると考えられる。

19世紀後期台湾で造られていた茶は福州由 来の鳥龍茶で, 島内中国人（福建人が主であ るが）の消費のほか一部の茶が福建に送られ ていだ”。本格的に烏龍茶の生産が台湾で始 まるのは，1858年天津条約で安平港と淡水港 が国際通商港として開港してからである。

1865年 John Dodd (英国, 茶商) は台湾が 茶栽培適地であることに着目し； 5 年間かけ て安溪から大量の茶苗を持ち込み北投, 桃園, 竹園, 苗栗各県に植栽するとともに, 福州か ら烏龍茶の精製加工技術を導入し，1869年に は製茶工場を台北に建設した。そして1872年 には台北に 5 社の茶輸出商社ができ, 台湾茶 の本土及びアメリカへの輸出が順調に伸びて いった。当時の主な茶産地として台湾北部の 新竹, 七星, 文山があげられる5)。 


\section{5 包種茶の生産}

台湾の鳥龍茶の生産が1870年代から急速に 進んだことと，世界経済不況のあおりを受け て翰出不振がかさなり, 台北茶市場には茶が 滞貨して茶価は低落した。そこで鳥龍茶を福 州で着香して，東南アジアに輸出するように なった。これが台湾包種茶の始まりである。 1881年になると泉州の呉福源, 安渓の王安定, 張古魁等が来島し包種工場 (着香工場) を建 設し，ここで着香した着香鳥龍茶をアモイ経 由にて南洋に輸出した。

1885年台湾が日本領になって早々，安渓の 王水錦, 魏静が来島, 台北南港大杭にて茶栽 培と包種茶製造を始めた ${ }^{5)}$ 。この時代台湾で 主に造られていた鳥龍茶も花香茶でこれを裹 づけるものとして, 台湾茶業界誌「台湾之茶 業」には昭和 10 年代迄，茶況のほかに花茶製 造用料花の市況が載つている。

1895年台湾が日本領土と成つてからは，台 湾総督府は茶業試験場を設立して台湾茶業と くに鳥龍茶の発展に努力した。台湾茶業は福 建の優良品種, '青心烏龍, 大葉烏龍, 鉄観音' 等を, 茶樹生育に適した土壤, 気象条件の新 開地に植栽したことと, 新しい農業技術の導 入もあって短期間で茶園形成に成功した。こ うして20世紀始めには7,500tの鳥龍茶をアメ リカに輸出するようになり, その輸出量は中 国本土を凌駕するまでに成長した。しかしそ の後ジャバ紅茶がアメリカに登場するにおよ び, 台湾鳥龍茶はアメリカ市場を失い, また 南西太平洋で戦時色が強まるとともに台湾茶 の輸出が低落していった。明治末から太平洋 戦争迄の, 台湾での茶の生産統計を示したの が表 1 である。

\section{6 台湾包種茶}

現在台湾銘茶として有名な, 文山包種は何 時頃誕生したのであろうか。大正末，1923年 の「台湾之茶業，12巻，6号）を見ると，「最 近着香しなくとも芳香を持つ包種茶が造られ るように成つた。という記事が載っている。 これから見て台湾では1920年代初めに着香し
ない包種茶が試作されたものと考えられる。 この試作に貢献したのが前出の王水錦（1923 没)といわれている。

包種茶と烏龍茶の製造工程仙基本的には変 わりないが，両茶種間には発酵程度に差があ る。即ち前者法後者よりも発酵度が低く，前 者の外観は青緑色を带び, 後者は褐色である。 液色は前者は黄橙色, 後者の液色は濃い橙色 である。この発酵度の差は摘採した茶葉を先 ず日干する際の時間の長短，その後陰干して いる間の茶葉の手による摫抖揉捻程度の回数 と強弱に由来する。なお発酵程度を茶タン二 ンの酸化程度であらわすと, 文山包種：8 ～20\%, 凍頂茶： $20 \sim 30 \%$ (以上台湾包種茶), 台湾鉄観音: 30 40\%, 台湾鳥龍茶： 50〜 60\%といわれている。このような発䣲度 の低い半発酵茶が作られたのは, 発酵初期に 茶葉から馥郁とした花香が生まれてくること に農民が気づいたことによる。

この包種茶創製の成果には茶品種選抜の努 力が大きく寄与している。1910～1917年にわ たり総督府草湳坡茶試験場（平鎮試験場の前 身)で，早生種'大葉鳥龍，硬枝紅心’，中性種 '青心大友'，晚成種'青心鳥龍'を中心に，その 他台湾で栽培されていた茶樹を集めた栽培, 製茶試験が行はれている。その後これら試験 品種の内で栽培農家に広く普及したのが, 台 湾包種茶最適品種としての‘青心烏龍’と“青心 大友'で，1994年には台湾茶園21,241haのう ち, 前者が $48 \%$, 後者が $19 \%$ を占めるに至っ ている。

‘青心鳥龍’は灌木性中葉種で, 安渓が原産地 で台湾には早くから導入されていた品種であ る。“青心大右”も灌木性中葉種で, 台湾文山の 茶畑から選抜された品種である11)。“青心大友” の選抜母樹についての記録は未詳であるが, 19世紀中期安渓から導入され文山で植栽され た青心系統の実生茶樹群の中から農民の手で 選抜されたものと考えられる。これらの品種 加ら包種茶を造ると, 芳香成分であるリナ ロール,ゲラニオール, 2 -フェニルェ夕ノー ル, ベンジルアルコール, ジャスミンラクト ン等の花香成分を大量に生成し，高い花香が 
生まれてくる゙〉。

このように台湾包種茶は1920年代に創作さ れたが，当時は廉価な花香茶の生産と輸出が 台湾茶業界の最大の課題であり，また間もな く太平洋戦争も始まり, しばらくは茶業界か らその存在を忘れられていた。やがて1945年 台湾が中国復帰し茶業が再興されてから, 文 山包種, 凍頂茶として日の目を見るように なった。その後台湾茶業は幾多の変遷を繰り 返し，現在では台湾茶は島内消費を中心とし た状況で，生産される茶種は烏龍茶が殆どで ある。そのなかで台湾包種茶は台湾銘茶とし て台湾茶業に重要な地歩を築いている。一方 花香茶の生産は現在行はれていない。

\section{7 結产}

包種茶は安渓でまず着香鳥龍茶 (花香茶) として生まれ，主に南洋向け貿易品として生 産された。その後台湾茶業が成長するととも に, 海外での鳥龍茶に占める台湾茶の比重が 增大し, 福建では着香烏龍茶の生産は停止し た。一方台湾では福建に代わり着香鳥龍茶が 生産されていたが, 鳥龍茶の生産改良の過程 で, 高い花香を持つ茶の製造に成功し台湾包 種茶が誕生した。現在台湾の茶生産と消費は 烏龍茶が主体で，そのなかで香味に優れた台 湾包種茶は台湾銘茶として広く知られるよう なった。

表 1 台湾茶統計

\begin{tabular}{|c|c|c|}
\hline 年 度 & 烏龍茶 & 包種茶 \\
\hline 1900 & $7,051 \mathrm{t}$ & $1,313 \mathrm{t}$ \\
1920 & 2,880 & 3,779 \\
1926 & 4,790 & 5,389 \\
1930 & 3,179 & 4,626 \\
1940 & 1,487 & 2,326 \\
\hline
\end{tabular}

（台湾輸出百年簡歴, 1965）

最後に本稿をまとめるにあたり，元台湾茶
業改良場研究員（秘書）徐英祥氏に，文献の 収集にご協力頂きましたことを記して深謝い たします。

\section{8 文献}

1) 陳宗惁主編 (1992): 茶類篇, 中国茶経, 上海出版社 (上海), p.121, 235.

2 ) 竹尾忠一 (2000)：紅茶の起原, 茶研報 No.89, 59-63.

3 ）蔡盛林総編 (1988)：鉄観音，中国農業百 科全集

「茶業巻」, 農業出版社（北京） p, 294.

4) 竹尾忠一, 津志田藤二郎, P.K.Mahanta, 田代正樹, 今村義成 (1983)：烏龍茶と紅 茶の香気に関する食品化学的研究, 茶試研報, No.60，91-180。

5 ）林橎泉（1956）：烏龍茶及包種茶製造学, 第 2 章.

台湾省農林庁茶業伝習所, p.5-10.

6 ）呉振鐸 (1991)：閩台適製半発酵茶類四個 地方名種的比較, 福建省茶葉学会, 福建 茶業 (福州)， p.6-29.

7 ）吳振鐸，馮㯺淮，蔡俊明 (1990)：台湾眉 原山野生茶樹形態之観察, 中国古茶樹, 中国古茶樹遺伝保護検討会論文集，上海 文化出版社（上海）， p.72-83.

8 ）福建省農業科学院茶葉研究所編 (1979)： 茶樹品種志, 福建人民出版社（福州）, p.116.

9) 廖慶梁：「台湾の茶文化と科学」, お茶の鄉講演会講演要旨，2000，7月.

10）呉覚農主編 (1990)：淡水汀志, 中国地方 志茶葉歷史資料選輯, 農業出版社 (北京), p. 363 .

11）蔡盛林総編 (1988)：青心大友, 中国農業 百科全集, 「茶業巻」, 農業出版社(北京), p. 265 . 